\title{
The grapevine aphid Aphis illinoisensis: a good example of recent invasion and rapid colonization by aphids
}

\author{
D. Mifsud ${ }^{1}$ and N. Pérez Hidalgo² \\ ${ }_{1}^{1}$ Junior College, Department of Biology, University of Malta, Msida MSD 1252 (Malta); e-mail: david.a.mifsud@um.edu.mt \\ ${ }^{2}$ Department of Biodiversity and Environment Management, University of León, E-24071 León (Spain)
}

\begin{abstract}
Aphis illinoisensis represents one of the most recent aphid invaders from the New World to the Mediterranean Region. This aphid, which is native to North America and is now widely distributed in Central and South America, was first found in Southern Turkey in 2002, and in 2005 it was also found in Crete (Greece). Thereafter it was recorded from Northern Cyprus, Israel, Tunisia, Algeria, Montenegro and Libya, and is now probably present throughout the Mediterranean. The present work provides data on the presence of this aphid in the Maltese islands, a group of low-lying islands situated in the central Mediterranean Basin.
\end{abstract}

One of the most recent alien aphids introduced from the Nearctic Region and established in the Palaearctic Region is the grapevine aphid, Aphis illinoisensis (Shimer, 1866) (Coeur d'acier et al., 2010). The species is heteroecious holocyclic in North America, with Viburnum prunifolium as a primary host and several species of Vitaceae (Ampelocissus, Cissus, Parthenocissus and Vitis) as secondary hosts, and it is likely to be anholocyclic on vines in warmer climates and glasshouses in other parts of the world (Blackman \& Eastop, 2000, 2006). In the New World, the species is considered to be a pest of grapevines, but so far records from the Palaearctic territories are citing this aphid as a minor pest (e.g. Barjadze \& Ben-Dov, 2011). Aphis illinoisensis is a vector of watermelon mosaic virus (Webb et al., 1994); there is no evidence of transmission of grapevine viruses by this aphid (Kuniyuki et al., 1995). The parasitoids associated with this aphid in the Mediterranean Region were reviewed by Havelka et al. (2011).

Since its accidental introduction in Turkey in 2002 (Remaudière et al., 2003), this species has been recorded practically throughout the Mediterranean Basin (Fig. 1). There are published records of A. illinoisensis from Greece (Tsitsipis et al., 2005), Israel (Quirós et al., 2009; Barjadze \& Ben-Dov, 2011), Tunisia (Kamel-Ben Halima \& Mdellel, 2010), Algeria (Laamari \& Coeur d'acier, 2010), Montenegro (Petrović-Obradović et al., 2010) and Libya (Havelka et al., 2011).

The aphid fauna of the Maltese islands is poorly known. Mifsud et al. (2009) provided an overview of all aphid records from Malta and published a list of the 50 aphid species so far known from the territory. In a work related to aphids on crop plants, herbaceous and woody shrubs, Mifsud et al. (2011) recorded some 60 additional new records of aphids from the Maltese islands, which included A. illinoisensis. Due to the importance of this exotic aphid as a pest of grapevines, these records are being presented here for the first time. In 2009, A. illinoisensis was found on Vitis vinifera on mainland Malta as follows: Msida (university grounds), 2009-06-01, apterae attended by Cre- matogaster scutellaris (Hymenoptera: Formicidae), collected by D. Mifsud; Qormi, 2009-06-25/2009-08-13/2009-09-28; apterae attended by Tapinoma nigerrimum (Hymenoptera: Formicidae), collected by E. Azzopardi; Rabat (Buskett area), 2009-09-30; apterae, collected by E. Azzopardi; Hal-Far, 2010-06-20; apterae and alatae, collected by D. Mifsud; Zejtun, 2010-07-13; apterae, collected by D. Mifsud.

Aphis illinoisensis was first noted in Malta in 2009, but the high level of infestations and extensive damage observed at that time indicate that the species was probably introduced earlier. In the Hal-Far area (in the far south of Malta), the species was observed in both private gardens and open fields, and high infestations of this aphid indicate that it is developing locally into a major pest of grapevine.

\section{Acknowledgements}

The authors thank E. Azzopardi for assistance in field sampling of this aphid and G.W. Watson for providing assistance with literature on the species. The authors also thank D. Dandria for critically revising the present note.

\section{Le puceron de la vigne Aphis illinoisensis: un bon exemple d'invasion récente et de rapide colonisation par des pucerons}

Aphis illinoisensis représente uns des pucerons envahissants les plus récents du Nouveau Monde vers la région méditerranéenne. Ce puceron, qui est originaire d'Amérique du Nord et est désormais largement répandu en Amérique centrale et du Sud, a été trouvé pour la première fois dans le sud de la Turquie en 2002 et également en 2005 en Crète (Grèce). Par la suite, il a été signalé dans le nord de Chypre, Israël, la Tunisie, l'Algérie, le Monténégro et la Libye et est désormais probablement présent dans l'ensemble de la région méditerranéenne. Cet article présente des données sur la présence de ce puceron dans les îles maltaises, un 


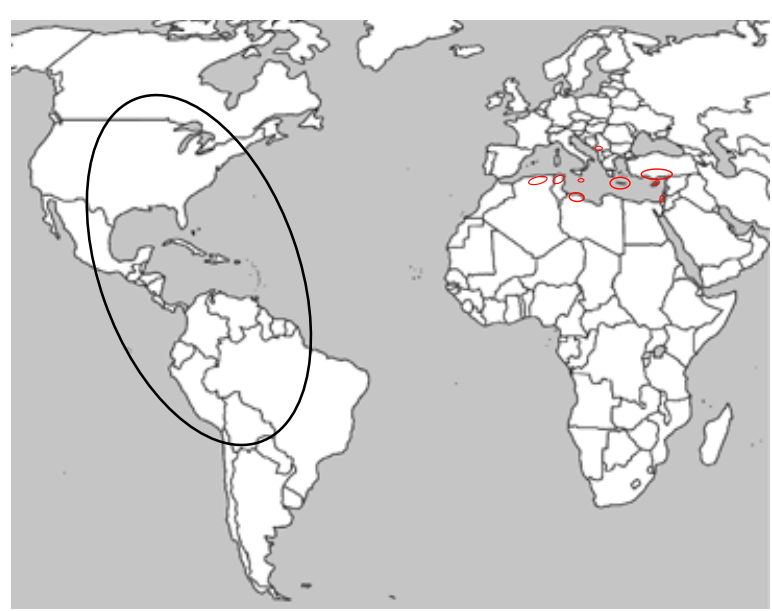

Fig. 1 Distribution of Aphis illinoisensis: black, native range; red, regions of introduction and establishment in the Mediterranean.

groupe d'îles de faible altitude situées au milieu du bassin méditerranéen.

\section{Тля виноградной лозы Aphis illinoisensis: хороший пример недавней инвазии и быстрой колонизации тлями}

Aphis illinoisensis, представляет собой одну из самых новых инвазивных тлей, попавших из Нового мира в регион Средиземного моря. Эта тля, которая является аборигенной в Северной Америке и в настоящее время широко распространена в Центральной и Южной Америке, была впервые найдена в южной Турции в 2002 году, а в 2005 году она была также найдена и на острове Крит (Греция). Затем она была зарегистрирована на севере Кипра, в Израиле, Тунисе, Алжире, Черногории и Ливии и теперь, по-видимому, присутствует повсюду в Средиземноморском регионе. Данная работа представляет данные по присутствию этой тли также и на мальтийских островах, т.е. в группе низкоуровневых островов, расположенных в центральной части Средиземноморского бассейна.

\section{References}

Barjadze S \& Ben-Dov Y (2011) The grapevine aphid Aphis illinoisensis: an invasive pest in Israel. Phytoparasitica 39, 55-57.

Blackman RL \& Eastop VF (2000) Aphids on the World's Crops. An Identification Guide, 2nd edn. J. Wiley \& Sons, Chichester, viii + 466 pp.

Blackman RL \& Eastop VF (2006) Aphids on the World's Herbaceous Plants and Shrubs (Volume 1 Host Lists and Keys/Volume 2 The aphids). J. Wiley \& Sons, Chichester, viii + 1439 pp.
Coeur d'acier A, Pérez Hidalgo N \& Petrović-Obradović O (2010) Aphids (Hemiptera, Aphididae). Chapter 9.2. In: Roques A. et al. [eds.] Alien terrestrial arthropods of Europe. BioRisk 4(1): 435-474. doi: 10.3897/ biorisk.4.57.

Havelka J, Schukshuk AH, Ghaliow M, Laamari M, Kavallieratos NG, Tomanović Ž, Rakhshani E, Pons X \& Starý P (2011) Review of invasive grapevine aphid, Aphis illinoisensis Shimer and native parasitoids in the Mediterranean (Hemiptera, Aphididae; Hymenoptera, Braconidae, Aphidiinae). Archives of Biological Science 63(1), 269-274.

Kamel-Ben Halima M \& Mdellel L (2010) First record of the grapevine aphid, Aphis illinoisensis Shimer, in Tunisia. Bulletin OEPP/EPPO Bulletin 40(2), 191-192.

Kuniyuki H, Yuki VA, Costa CL \& Costa AS (1995) Nao trasmissao de tres virus da videira atraves do afideo Aphis illinoisensis. Fitopatologia Brasileira [No evidence for transmission of these grapevine viruses by the aphid Aphis illinoisensis] 20, 513-514. (In Portuguese)

Laamari M \& Coeur d'acier A (2010) Le puceron de la vigne Aphis illinoisensis arrive en Algérie. Bulletin OEPP/EPPO Bulletin 40(1), 167-168.

Mifsud D, Pérez Hidalgo N \& Barbagallo S (2009) Present status of aphid studies in Malta (Central Mediterranean) with special reference to tree dwelling species. Redia 92, 93-96.

Mifsud D, Mangion M, Azzopardi E, Cuesta Segura D, Watson GW \& Pérez Hidalgo N (2011) Aphids associated with herbaceous plants, shrubs and crops in the Maltese Islands (Hemiptera: Aphidoidea). Bulletin of the Entomological Society of Malta 4, in press.

Petrović-Obradović O, Tomanović Ž, Poljaković-Pajnik L, Hrnčić S, Vučetić A \& Radonjić S (2010) New invasive species of aphids (Hemiptera, Aphididae) in Serbia and Montenegro. Archives of Biological Sciences, Belgrade 62(3), 775-780.

Quirós DI, Remaudière G \& Nieto Nafría JM (2009) Contribución al conocimiento de Aphididae y Phylloxeridae (Hemiptera: Sternorrhyncha) de Panamá [Contribution to the knowledge of the Aphidae and Phyloxeridae (Hemiptera: Sternorrhyncha) from Panama]. Neotropical Entomology 38, 791-800. (In Spanish)

Remaudière G, Sertkaya E \& Özdemir I (2003) Alert! Discovery in Turkey of the American aphid, Aphis illinoisensis, a grapevine pest (Hemiptera, Aphididae). Revue Francaise d'Entomologie 25, 170.

Tsitsipis JA, Angelakis E, Margaritopoulos JT, Tsamandani K \& Zarpas KD (2005) First record of the grapevine aphid Aphis illinoisensis in the island of Kriti, Greece. Bulletin OEPP/EPPO Bulletin 35(3), 541-542.

Webb SE, Kok Yokomi ML, Gray DJ \& Benton CM (1994) In vitro rearing of grapevine aphid (Homoptera: Aphididae) on micropropagated shoot cultures of bunch grape and muscadine plants. Annals of the Entomological Society of America 87(6), 879-885. 